\title{
Electoral Opportunism: Disentangling Myopia and Moderation
}

\author{
Axel Cronert and Pär Nyman*
}

February 9, 2021

\begin{abstract}
A central component of representative democracy, competitive elections imply that political incumbents face uncertainty about being re-elected into office. This study jointly considers two types of opportunistic behavior that may be triggered by such uncertainty - policy myopia and policy moderation - which hitherto have been the focus of separate research traditions. Disentangling the two behaviors theoretically and empirically, we evaluate their prevalence in economic policy-making among Swedish local governments. To this end, we apply a new measure of electoral competitiveness that captures the incumbent government's re-election probability, for which plausibly exogenous variation is generated by exploiting national-level vote intention polls. We find a substantial moderating effect of competitiveness on incumbents' tax rate decisions - shifting policy towards the median voter - but little evidence of policy myopia. Further corroborated by original survey evidence on politicians' perceptions of their re-election prospects and opportunistic policy options, these findings challenge the widespread notion that electoral opportunism is inherently short-sighted.
\end{abstract}

${ }^{*}$ Department of Government, Uppsala University. We are grateful to participants at the 2020 Council for European Studies and the 2020 Swedish Political Science Association conferences, and especially Olivier Jacques, Catherine Moury, and Patrik Öhberg, for valuable comments on earlier versions of this study. Thanks also go to Kåre Vernby for kindly sharing his survey data with us, and to Vinicius Ribeiro for excellent research assistance. Financial support from Forte, Swedish Research Council for Health, Working Life and Welfare [2017-01121] is gratefully acknowledged. 


\section{Introduction}

In the tradition of Schumpeter (1950, p. 269), freely contested elections, whereby political leaders acquire the power to govern through "a competitive struggle for the people's vote", are a central component of representative democracy (Dahl 1971; Elkins 1974; Robertson 1976; Sartori 1976; Strøm 1989). In this competitive conception of democracy, the method by which the people can ultimately control their leaders is by "refusing to reelect them" (Schumpeter 1950, p. 272). Accordingly, unless elections are entirely noncompetitive, political incumbents will always face some degree of uncertainty about their prospects of remaining in office beyond the current term. The more uncertain is the outcome, the more competitive the election is understood to be (Elkins 1974; Strøm 1990).

Questions of how and to what extent electoral competitiveness in turn affects democratic governments' policy-making - not least in the realm of economic policy - have been the topic of a myriad of studies in political science and economics; most of which can be linked to one of two ideas about two distinct types of opportunistic behavior ${ }^{1}$ (Frey and Schneider 1978). The first idea is that electoral competitiveness creates incentives for the governing parties to moderate their policy away from the more ideologicallyoriented positions embraced by their activists and financial supporters towards those of the median voter in order to strengthen their re-election prospects (Robertson 1976; Wittman 1983; Canes-Wrone and Shotts 2004). The second, more pessimistic - and overall more influential - idea holds that competitive elections rather leads to myopic policy-making, by tempting governments to seek to please voters by reducing taxes and/or increasing public consumption, effectively postponing debt reduction or public investments to the future (Nordhaus 1975; Rogoff and Sibert 1988; Jacobs 2011).

The vast scholarship associated with each of these ideas has evolved into two separate and seemingly unrelated research traditions with few, if any, touch-points to date. This separation is unfortunate considering that the two traditions to a large degree investigate similar types of policy and that, as we shall see, their two core ideas yield conflicting sets of implications about the policy effects of electoral competitiveness. Thus, which of the two types of opportunistic behaviors that dominates in actual policy-making is an empirical question which has yet to be investigated and which requires that the two are disentangled theoretically and empirically.

\footnotetext{
${ }^{1}$ By electoral opportunism we mean a practice of compromising or abandoning a preferred policy or principle, in the process of exploiting an opportunity to gain immediate electoral advantage.
} 
Against this background, the present study seeks to demonstrate how the relative importance of myopic and moderating effects of electoral competitiveness on economic policy-making can be assessed in a joint analysis, using panel data from around 1,000 election terms in Swedish local governments. In doing so, we address three shortcomings in previous literature, pertaining to the measurement of electoral competitiveness, the strength of causal inference, and the validity of underlying assumptions.

First, we apply a measure of electoral competitiveness recently developed by Cronert and Nyman (2020), which is based on predictions of the incumbent government's re-election probability at the time of policy-making. The measure has a number of advantages over the indicators used in previous research and is particularly useful in analyses of multi-party democracies.

Second, we propose a technique for strengthening causal inference in analyses involving this measure, by exploiting the interplay between local pre-conditions and trends in national-level vote intention polls to generate plausibly exogenous variation in the local incumbent's re-election probability.

Third, we take significant steps towards validating a number of important assumptions about politicians' perceptions and intentions that are generally taken for granted in studies of electoral opportunism. We do so by providing new survey evidence on incumbents' assessments of their electoral prospects, economic policy preferences, and views on opportunistic policy-making.

Our panel data analysis tracks how changes in incumbents' re-election probability over the election cycle affect their decisions about the local tax rate; a policy that is both salient and visible to voters and strongly linked to the dominant socio-economic left-right dimension. Consistent with the survey evidence, we find that incumbent governments moderate their tax policy towards the center when the vote intention polls signal increasing electoral competitiveness. By contrast, we find no systematic evidence of policy myopia, whether in taxation, budget balance, or public investments.

Our findings have important implications for research on electoral democracy. Challenging the overall dominance of the myopic perspective in analyses of the policy effects of competitive elections, they caution against overly pessimistic accounts of democratic policy-making. More broadly, they also demonstrate the benefits of using more sophisticated measurements and causal strategies than those commonly used in studies of electoral competitiveness.

\section{A Tale of Two Traditions}

The essence of the concept of electoral competitiveness lies in the uncertainty regarding what coalition, party or candidate will execute political 
power after the next election (Elkins 1974; Strøm 1990; Cronert and Nyman 2020). Looking back at the empirical research on the impact of democratic institutions on economic policy-making, one can delineate two principal, yet partly conflicting, ideas about how such uncertainty creates incentives for incumbent governments to engage in opportunistic policy-making. Both are concerned with how incumbents, assumed to have at least some office-seeking motivations, ${ }^{2}$ balance the trade-off between improving their prospects of being re-elected into office on the one hand, and various preferred policies or outcomes, on the other. However, while having been analyzed jointly in some early studies - notably that of Frey and Schneider (1978) - each of the two ideas soon became the focal point of a separate research tradition, between which there have been few, if any, touch-points over the years.

\section{Electoral Competitiveness and Policy Myopia}

Research in first tradition holds that higher electoral competitiveness leads to a more myopic policy-making behavior (Frey 1978). The underlying assumption is that by imposing some combination of reduced taxes and/or increased public consumption, the incumbent government can improve its popularity among voters - and thereby its re-election prospects - while effectively postponing debt reduction or public investments to the future (Frey and Schneider 1978; Rogoff 1990; Jacobs 2011).

Previous research has pointed out a number of potential sources of a temporal bias among voters that makes them susceptible to such opportunistic behavior by the government. A first such source could be a desire among voters of today to exploit future generations - who naturally cannot vote - by supporting short-sighted policies that result in large budget deficits while sending the bill to the future (Bowen, Davis, and Kopf 1960). Temporal bias would also occur if voter preferences for consumption were time-inconsistent, such that voters at any given time put higher value on their current level of consumption than what they would do in a prospective or retrospective evaluation (Strotz 1955). Other potential sources of myopia are not based on the assumption that voters care less about the future. One holds that because voters are better informed about the present consequences of the incumbents' policy than about its future consequences, they are likely to give higher weight to the former when deciding on whom to cast their votes (Kramer 1971; Nordhaus 1975; Rogoff and Sibert 1988). A related argument rather focuses on voters' tendency to economize on cognitive effort when

\footnotetext{
${ }^{2}$ The value of holding office may be either intrinsic or instrumental, i.e., useful as a tool to achieve policy goals.
} 
making such decisions (Jacobs 2011).

These voter characteristics have all been pointed out as creating incentives for governments to make short-sighted policy decisions. Such incentives may, however, also stem not from voters' myopia but simply from their disagreement. Given that voters - and consequently the parties competing for office - have conflicting preferences regarding the composition of public spending, a governing party that anticipates a higher risk of being replaced by an adversarial may have stronger incentives to spend on its preferred policy while issuing debt that needs to be repaid by the successor, thereby reducing the next government's room for maneuver (Alesina and Tabellini 1990). In a related model, where parties disagree about the level rather than the composition of spending, only governments that prefer low public spending have a myopic bias (Persson and Svensson 1989).

Questions about the relative merit of each proposed mechanism need not detain us here. It is worth noting, however, that the aforementioned factors are often thought of as generating an essentially unconditional myopic bias in democratic policy-making (e.g., Eslava 2011). However, considering that a government's short-sighted behavior can be expected to come at the expense of other values - such as its preferred policy, its reputation, and future macro-economic performance - it follows that it should have less to gain from engaging in such behavior when its prospects of remaining in office are certain than when they are not (Schultz 1995; Price 1998).

Early works on myopic policy-making that take this crucial insight to heart include the theoretical contributions by Rogoff and Sibert (1988) on taxation and Alesina and Tabellini (1990) on public debt. Among the first empirical studies of policy myopia to account for variation in governments' re-election prospects were Schultz (1995) on government transfer payments in Britain and Clingermayer and Wood (1995) on public debt in the American states. Later studies include Price (1998), Pettersson-Lidbom (2001), Alt and Rose (2007), Aidt, Veiga, and Veiga (2011), Efthyvoulou (2012), Immergut and Abou-Chadi (2014), Hübscher and Sattler (2017), and Seiferling (2020).

\section{Electoral Competitiveness and Policy Moderation}

Work in the second research tradition instead assumes that higher electoral competitiveness incentivizes incumbent governments to moderate their policy positions so that they better align with that of the median voter and thus appeal to a larger portion of the electorate. When the ruling party or parties are more certain about the electoral outcome, they can instead put more emphasis on implementing their preferred ideologically-oriented policies (Frey and Schneider 1978; Wittman 1983). 
In principle, this behavioral logic would occur for an incumbent government operating as a unitary actor, for which policy moderation generally constitutes a vote-maximizing strategy (cf. Downs 1957). However, similar implications follow from a more complex and likely more realistic model where the governing party comprises groups with partly different preferences for office- and policyseeking (Robertson 1976; Abou-Chadi and Orlowski 2016). Party leaders, who tend to receive the highest payoffs from staying in office, have stronger incentives to steer policy towards the median voter. Doing so, however, risks coming at the expense of resources (e.g., time and money) devoted by party activists or financial supporters, whose number and motivation depend on parties' policy goals, and whose policy preferences are generally more extreme than those among voters at large. In this model, the expected degree of electoral competitiveness is a key determinant for whether the party leaders' preferences for policy moderation are likely to become dominant (Robertson 1976; Abou-Chadi and Orlowski 2016).

Relatedly, in cases where coalition governments face increasing competitiveness, diverging strategic preferences may occur between coalition partners that are large mainstream parties and those that are small and/or niche parties, since for the latter policy moderation may not be a vote-maximizing response (Abou-Chadi and Orlowski 2016). Still, there are reasons why also coalition governments may respond to increased competitiveness with policy moderation. Given that the junior coalition parties are also to some extent office-seeking, they may support a moderating strategy if they expect it to improve their their coalition prospects. Policy moderation could also occur simply from the larger mainstream parties having stronger relative influence over economic policy.

Recent decades have seen a growing number of empirical studies in this tradition, analyzing policy moderation in terms of changes in the left-right dimension of party programs (e.g., Abou-Chadi and Orlowski 2016), in US presidential budgetary proposals (Canes-Wrone and Shotts 2004), in voting behavior in the US House of Representatives (Lee, Moretti, and Butler 2004), and in policy implemented by incumbent governments (Boyne 1998; Hobolt and Klemmensen 2008; Soroka and Wlezien 2010; Bernardi 2018; Abou-Chadi and Immergut 2019).

\section{Juxtaposition of the Traditions: The Case of Taxation}

It follows from the behavioral logics of both aforementioned research traditions that we should expect incumbent governments to adjust their economic policy in response to higher electoral competitiveness. However, once the government's ideological orientation is taken into account, the two traditions 
yield conflicting sets of expectations about the direction of those policy adjustments. Usefully, this creates an opportunity for evaluating which logic is the more dominant in a given political context, by comparing the behavior of governments with different ideological orientations that find themselves in a similar electoral situation. However, to our knowledge, this opportunity has not been exploited since the work of Frey and Schneider (1978).

For the sake of simplicity, let us illustrate this argument focusing on two parties - a left-wing party and a right-wing party - that compete for government office on a single conflict dimension concerning the size of the public sector, where the left-wing party prefers a higher level of taxation (and, accordingly, government spending) than the right-wing party. We assume that voters base their decisions on the behavior of incumbents and incumbents can choose their policy strategically in anticipation of such voter behavior.

In this situation, the income tax rate is a policy instrument that can be used opportunistically for both moderating and myopic purposes. Because taxation is subject to ideological conflict along the left-right dimension, it can be useful to modify for governments that seek to shift their policy profile towards the center. At the same time, an unfunded tax reduction in the present will generate a budget deficit that needs to be re-balanced at some point in the future.

Accordingly, in a scenario where the incumbent government's electoral considerations follow a myopia logic, we would expect that

- $H_{1}$ : When the government faces increased electoral competitiveness, the tax rate will on average be reduced (or not increased as much).

By contrast, if incumbent governments respond according to a moderation logic, we would expect that

- $H_{2}$ : When facing increased electoral competitiveness, the left-wing government will reduce (or refrain from increasing) the tax rate to a larger extent than the right-wing government.

So far, we have focused on how the incumbent government's economic policy is affected by the electoral competitiveness as conceptualized in the introduction; i.e, as the uncertainty regarding the its return to office, which peaks when its re-election probability $p$ is 0.5 since a dichotomous outcome cannot be more uncertain than $50 / 50$. It is worth noting, however, that studies vary in terms of how they expect incumbents' behavior to change as $p$ moves from 0 to 1 .

Some studies in both traditions expect the opportunistic effect to be a monotonic function of $p$ or - equivalently - of the government's popularity 
as gauged by some type of expected vote margin. ${ }^{3}$ This line of reasoning implies that it is the government's electoral vulnerability $(1-p)$ that triggers the opportunistic behavior. Others instead expect that the opportunistic effect peaks when uncertainty is at its highest, thus implying that what triggers the opportunistic behavior is the degree of electoral competitiveness $(1-|p-0.5|)$ rather than the degree of electoral vulnerability. ${ }^{4}$ In effect, the expectations derived from these two perspectives are equivalent in regards to situations where $p>0.5$, but opposite for $p<0.5$. Since disentangling these effects is difficult - particularly considering that in the Swedish case under consideration incumbent governments seldom face a very low re-election probability - we base our main test of the two hypotheses on the vast majority of cases for which $p$ is estimated at 50 percent or more (see below).

\section{Case Overview: Swedish Local Governments}

We will test the two hypotheses on the case of Swedish local governments, which provides detailed and consistent political and economic data for up to 290 municipalities observed annually between 1998 and 2018. The large number of observed political entities, and the fact that they operate under the same institutional framework and have a set of competing parties that is relatively stable across both space and time let us avoid a number of pitfalls associated with cross-national studies (Pettersson-Lidbom 2001; Aidt, Veiga, and Veiga 2011). As we shall see, another advantage of this case is that it provides rich individual-level data from two recent surveys of politicians, which allow us to validate the key assumptions that underpin our analyses more systematically than commonly done in research on electoral opportunism.

Electoral competition in Swedish municipalities follow a similar logic to many other proportional representation (PR) systems (Bäck 2003). Municipalities are governed by a local council to which members are elected from multi-member electoral districts in September every fourth year. The strong proportionality of the system makes it plausible that the median voter-rather than the voters in any particular individual district - is the pivotal actor in the electoral contests, which is an important assumption underlying the policy moderation response theorized above (Hobolt and Klemmensen 2008).

Swedish municipalities have a 'quasi-parliamentary' system, in which a

\footnotetext{
${ }^{3}$ See Alesina and Tabellini (1990), Schultz (1995), and Clingermayer and Wood (1995) on myopia, and Hobolt and Klemmensen (2008), Soroka and Wlezien (2010), and Pickup and Hobolt (2015) on moderation.

${ }^{4}$ See Price (1998), Alt and Rose (2007), Efthyvoulou (2012), and Seiferling (2020) on myopia, and Canes-Wrone and Shotts (2004) on moderation.
} 
majority coalition (or party) in the council appoints the Mayor and the committee chairs. This coalition (or party) is commonly regarded as the equivalent of a national government (Bäck 2003; SKR 2018). Swedish local governments are both functionally and politically strong in international comparison (Kuhlmann and Wollmann 2014). They are responsible for a large number of policy areas - including education, social care services, social assistance, housing, environmental and health protection, waste and sanitation, and water and sewerage - and account for more than 50 percent of total public employment and 27 percent of total public expenditure. Most local government operations are financed through a local income tax, which is determined by the local council before the end of November each year, as part of its decision on the following year's budget. Provided that the budget is planned to achieve balance, and deficits are corrected within three years, municipalities are free to set whichever tax rate they see fit (Folke 2014).

Previous research has shown that the local governments in Sweden can use their strength and autonomy for opportunistic purposes. For instance, Pettersson-Lidbom (2001) found that right-wing incumbents accumulate more debt when their probability of re-election is lower (while left-wing incumbents respond in the opposite way), and Svaleryd and Vlachos (2009) found that incumbent governments extract larger legal rents - measured as financial support to political parties - when their re-election prospects are stronger.

\section{Validation of Individual-level Assumptions}

Like any other analysis of electoral competition, ours rely on a number of behavioral assumptions about voters and about the politicians in the competing parties. To ensure that these assumptions are valid, we here bring in a combination of existing evidence and new individual-level data from two recent surveys.

\section{Left-Right Competition and Taxation Preferences}

A first crucial assumption is that the competition for votes predominately plays out along a single socio-economic left-right dimension. Swedish local councils typically consist of between 5 and 9 parties, most of which are locallevel branches of the eight dominant national parties: the Left Party, the Social Democrats and the Green Party (generally seen as left-of-center) and the Center Party, the Liberal Party, the Conservative Party, the Christian Democrats, and the Sweden Democrats (generally seen as right-of-center). Among these parties, policy positions mostly vary in a two-dimensional policy 
space, where the left-right dimension has persistently been the dominant one since at least the 1880s (Oscarsson and Holmberg 2016). The left-right dimension is also reflected in parties' coalition patterns; a large majority of the observed governing coalitions includes only parties on either the left-of-center or the right-of-center as enumerated above (69 percent among those formed after the elections in 1998-2014) (SKR 2018).

The most valid policy instrument for capturing the left-right dimension in our subsequent analyses is the local income tax rate - an instrument over which the local politicians have ample and sole discretion, and for which measurement error is low. ${ }^{5}$ Importantly, as noted above, the local councils' yearly tax rate decisions can be used opportunistically - not only for myopic purposes, but also for moderation since they are subject to substantial ideological conflict. Indeed, at odds with a common notion that parties do not matter for local governments' policy (Ferreira and Gyourko 2009), in Swedish municipalities left-wing governments have been found to tax and spend significantly more than right-wing governments (Pettersson-Lidbom 2008).

Substantial left-right differences in regards to taxation are also evident in individual-level data from a survey conducted by Dancygier et al. (2020) in 2017. This survey is particularly useful for our validation purposes because it includes a sample of people eligible to vote $(N=2,931)$ as well as a sample of local politicians $(N=3,455) .{ }^{6}$ The relevant conflict dimension is captured by a question about respondents' attitudes towards a proposal to "raise the municipal tax rate in order to improve public services", which was rated on a five-level Likert item ranging from "very good" to "very bad".

Figure 1 shows how the politicians' attitudes towards this matter differ across parties and how they compare to that of the median voter. Two clear blocs emerge in line with the enumeration above: a left-wing bloc consisting of three parties whose average politician holds a positive attitude to tax increases, and a right-wing bloc with four parties whose average politician is of the opposite opinion. ${ }^{7}$ The median voter is found in the middle, comfortably situated between the two blocs. Consequently, a majority of voters are located to the left of the right-wing bloc and to the right of the left-wing bloc, which makes policy moderation a viable option for both blocs.

It is also worth emphasizing that tax changes are common, salient and

\footnotetext{
${ }^{5}$ These circumstances make the tax rate superior to indicators of current expenditures, which are naturally more susceptible to impacts from factors beyond direct control of local politicians, and which we have found to be marked by idiosyncrasies and errors.

${ }^{6}$ Both samples were randomly drawn from population-wide registers and weights are used to adjust for systematic non-response. See Dancygier et al. (2020) for details.

${ }^{7}$ Since the Sweden Democrats were not included in any governing coalition before the 2018 election, we omit the party from this discussion.
} 


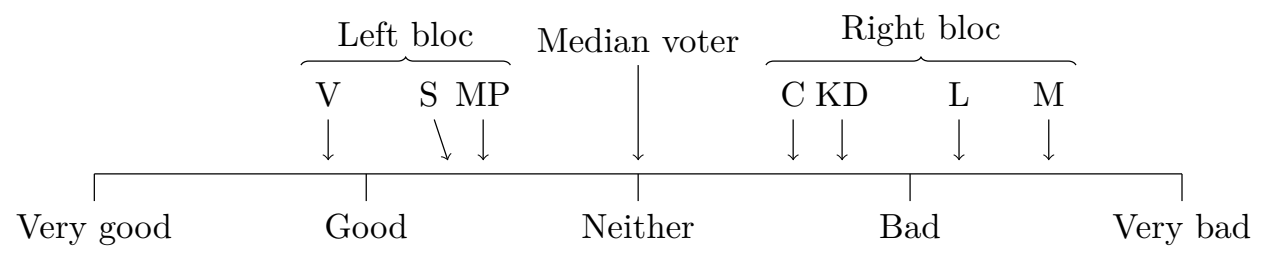

Respondents were asked about their attitudes towards raising the local tax rate to improve public service in their municipality. Responses were coded from 1 (very good proposal) to 5 (very bad proposal). The parties are the Left Party (V), the Social Democrats (S), the Green Party (MP), the Center Party (C), the Christian Democrats (KD), the Liberal Party (L), and the Conservative Party (M).

Figure 1: Local politicians' attitudes towards raising local taxes

visible to the Swedish voters. The data used in our main analysis records a change in the local tax rate on average every fifth year, 30 percent of which are cuts (Statistics Sweden 2020a). According to a question posed in a population-representative survey in the years 1998-2002, 90 percent of respondents view taxation as a rather important or very important issue (Weibull et al. 2014). Also, there is convincing evidence that Swedish voters observe how their disposable income is affected by tax policy changes, and take changes implemented during an election term into consideration when making their subsequent vote choice (Healy, Persson, and Snowberg 2017).

\section{Re-Election Prospects and Opportunistic Policy-Making}

Another important, yet largely unverified, assumption underlying the theories about both myopia and moderation is that when anticipating a competitive election - but less so otherwise - politicians are prepared to engage in opportunistic policy-making. We evaluate this assumption using an anonymous survey distributed in late 2020 to nearly all Swedish local council politicians. Almost 4,000 politicians participated; see the Supporting Information (SI, page S3) for details.

One survey question asked whether respondents "believe that the parties in the governing coalition would lose or gain votes" by taking different policy actions. The items included actions representing moderation ("policy is changed towards the political 'center"') as well as myopia ("unfunded tax cuts are implemented"), each of which was rated on a five-level Likert item ranging from "lose many votes" to "win many votes". The subsequent question read: "Suppose that the current governing coalition feels tempted to adapt its policies in order to be re-elected in the next election. How do you think 

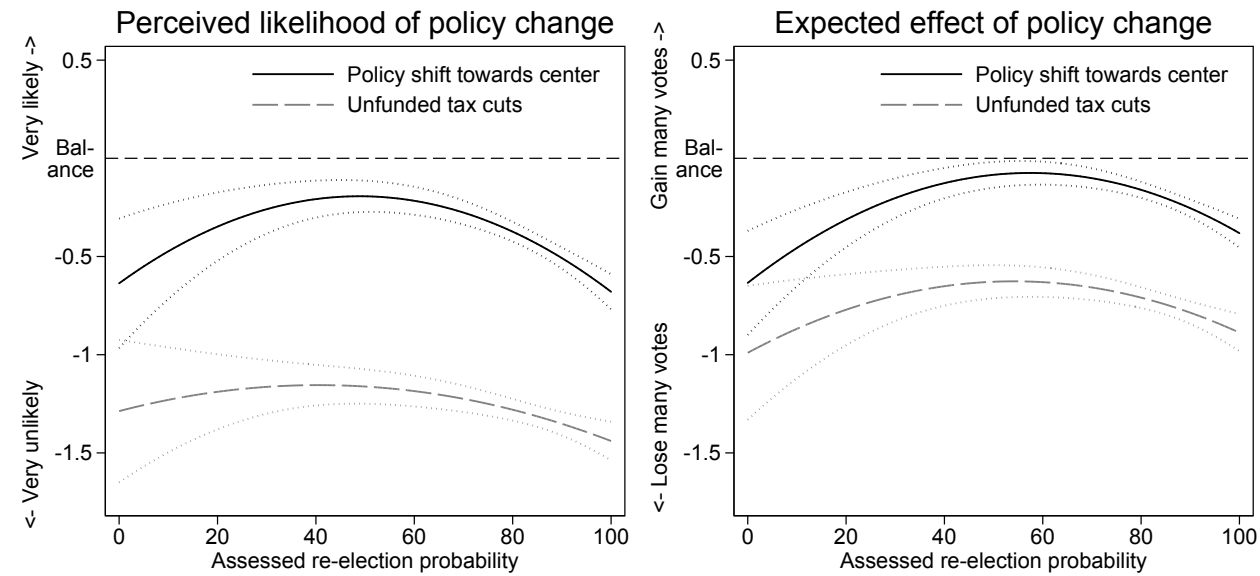

Lines are quadratic fits. Data include all incumbent politicians, $N=1,836$. Items range between -2 and 2. Dotted lines are 95-percent confidence intervals.

Figure 2: Incumbent politicians' perceptions of opportunistic policy actions, by their assessed electoral prospects.

such an adaptation would be reflected in the municipality's economic policy?" Here, respondents were asked to rate the likelihood of each policy action on a five-level Likert item ranging from "very unlikely" to "very likely".

Figure 2 reports the incumbent party politicians' answers to these two questions (scaled to range from -2 to 2), paired with data on their own assessment - at the survey date - of the probability that their party will be part of the governing coalition after the local elections in 2022, rated from 0 to $100(N=1,836)$. Each panel presents a quadratic fit of one's policy change ratings to one's assessed re-election probability. A first take-away is that neither policy option is regarded highly; on balance, both are perceived as relatively unlikely (left panel) and ineffective (right panel). Second, the average incumbent politician is nevertheless substantially more favorable towards moderation (mean: -0.41) than myopia (mean: -1.29$){ }^{8}$ Third, it is clear that incumbent politicians who expect a more competitive election (as $p$ approaches 50 percent) are significantly more likely to rate both the likelihood and the expected payoff of policy change higher - and more so for moderation. Thus, even though the re-election probability assessment was

\footnotetext{
${ }^{8}$ In fact, also opposition politicians $(N=1,518)$ believe that incumbents are more likely to enact policy shifts towards the center (mean: -0.12) than unfunded tax cuts (mean: $-0.46)$.
} 
made separately from the other survey questions, it appears that incumbents' views on the appropriateness of opportunistic policy actions are related to how competitive they expect the next election to be (cf. Schultz 1995).

Together with recent experimental evidence that Swedish local politicians observe and respond to trends in vote intention polls (Schumacher and Öhberg 2020), these observations provide an important micro-level foundation for the panel data analyses to which we turn shortly. First, however, we need to discuss how to best estimate the competitiveness of elections over longer periods, for which we have no politician survey data at hand.

\section{Measuring Electoral Competitiveness}

Most policy analysts would probably agree that ideal measures of electoral competitiveness in policy analysis would be based on truthful responses by incumbents to questions about the probability that they will remain in power after the next election, posed at the time of policy-making (Cronert and Nyman 2020; Boyne 1998). However, the difficulties involved in collecting consistent data on such responses across time and space have led scholars to resort to various proxy measures.

In our view, the measures used in the literature reviewed above suffer from two shortcomings that limit their applicability in the present analysis. First, most indicators are not expressed as probabilities. Rather, they typically take a linear or non-linear form of a vote share margin - such as that between the governing parties and the opposition parties (e.g., Bernardi 2018) or that between the leading or largest incumbent party and the largest opposition party (Bernardi 2018; Aidt, Veiga, and Veiga 2011; Efthyvoulou 2012) sometimes also taking into account the the historic degree of electoral volatility (Boyne 1998; Hübscher and Sattler 2017) as well as other variables related to the electoral context (Immergut and Abou-Chadi 2014).

Second, all of them, including those expressed in probabilistic terms-i.e., Kayser and Lindstädt's (2015) 'loss probability of the plurality party' and Abou-Chadi and Orlowski's (2016) 'likeliness of a vote-swing sufficiently large to alter a party's bargaining position in the legislature' - essentially only capture what Cronert and Nyman (2020) call pre-electoral competitiveness, i.e., the uncertainty about the result of the upcoming election. As such, these measures are blind to the post-electoral competitiveness, i.e., the uncertainty concerning who will form the government given a certain election result. For multi-party systems such as the one under consideration, where coalition governments are the norm and where parties differ systematically in their capability of translating parliamentary seats into cabinet seats, such measures 
of electoral competitiveness are thus less useful for capturing re-election prospects.

\section{An Estimate of the Incumbent Re-Election Probability}

To overcome these problems, we here apply the approach introduced by Cronert and Nyman (2020) to create a measure of electoral competitiveness which, in our view, comes closest so far to the ideal described above: it a) refers specifically to the incumbent government, b) is expressed in terms of the probability of its return to office after the next election, and c) varies over the election cycle to better approximate the involved politicians' perceptions of their re-election prospects at the time of policy-making.

As detailed in the SI (page S2), the approach involves a model that forecasts local parties' election results by combining data on prior local election results and party-specific data from annual national-level vote intention polls from Statistics Sweden $(2018 ; 2020)$. These forecasts are then plugged into a coalition formation model which has been fit previously based on parties' characteristics and observed coalition patterns. The output is an annual, municipality-party-specific prediction of the probability that the party will be part of the coalition that assumes power after the next election. Importantly, because of the timing of the polls this estimate refers specifically to November of each year -i.e., just around the time when the local tax rate and budget for the following year are decided.

To arrive at a measure of the incumbent government's re-election probability, $p$, we calculate a seat share weighted estimate of the re-election probability for the incumbent parties. ${ }^{9}$ The distribution of this measure for all observed municipality-years is plotted in the left panel of Figure 3, which shows a clear upward skew; for only 13.5 percent of the observations, $p$ is below 0.5. Lastly, we use these estimates to calculate our measure of electoral competitiveness as 1 less the absolute distance of $p$ from 50 percent $(1-|p-0.5|)$.

\section{Measurement Validity}

Assessing the measurement validity of these new probability estimates is crucial, and can be done by means of three exercises. The first exercise evaluates whether they correspond to the actual level of uncertainty in the sample for which we make predictions. If this were the case, there should be a 1:1 relationship between these predicted probabilities and the

\footnotetext{
${ }^{9}$ For robustness check purposes, we also create an alternative measure capturing the re-election probability of the largest incumbent party only.
} 

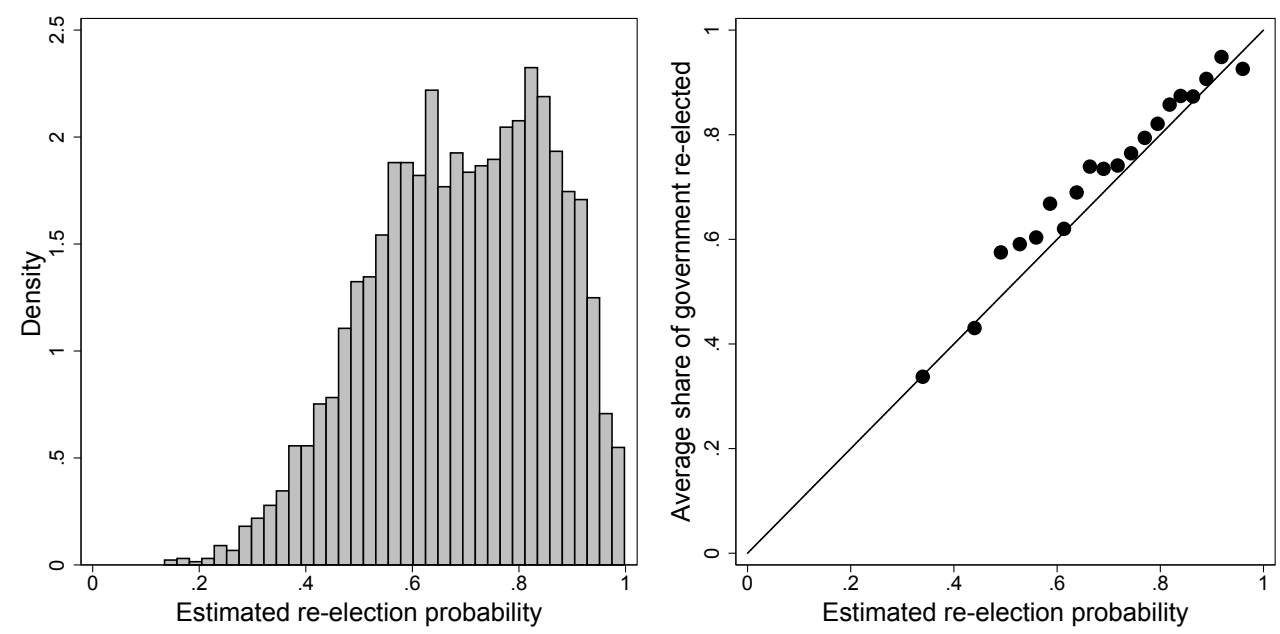

Figure 3: Estimated re-election probabilities for incumbent governments in 290 Swedish municipalities, 1998-2018.

outcome - that is, successful re-election into office - such that, for any given set of predictions, the share of successes should equal the average predicted probability. To evaluate this, the right panel of Figure 3 reports the share of successful re-elections into office over the estimated probability of success, with the observations being 'binned' into 20 ventiles based on the estimated probabilities. ${ }^{10}$ Although estimates just around 0.5 appear to be slightly underestimated, overall the bins lie reasonably close to the theoretical 1:1 relationship denoted by the diagonal line.

The second validity exercise considers how well these estimates capture the re-election probability assessments made by incumbent governments themselves. Here, we compare our probability estimates for November 2020 to those given by politicians in the contemporaneous survey described above.

For all survey respondents, there is a 0.40 correlation between our probability estimate for their party and their own assessment of that probability. However, a moderate individual-level correlation is not per se problematic for our purposes; rather, what matters is whether the measures converge when we aggregate assessments over larger groups that better approximate the actual decision-making bodies in governing coalitions. The left panel of Figure 4 shows how the correlation between our re-election probability of the incumbent governing coalition and the average assessment among respondents

\footnotetext{
${ }^{10}$ For coalition governments, the re-election indicator represents the seat share-weighted percentage of coalition parties that were re-elected.
} 

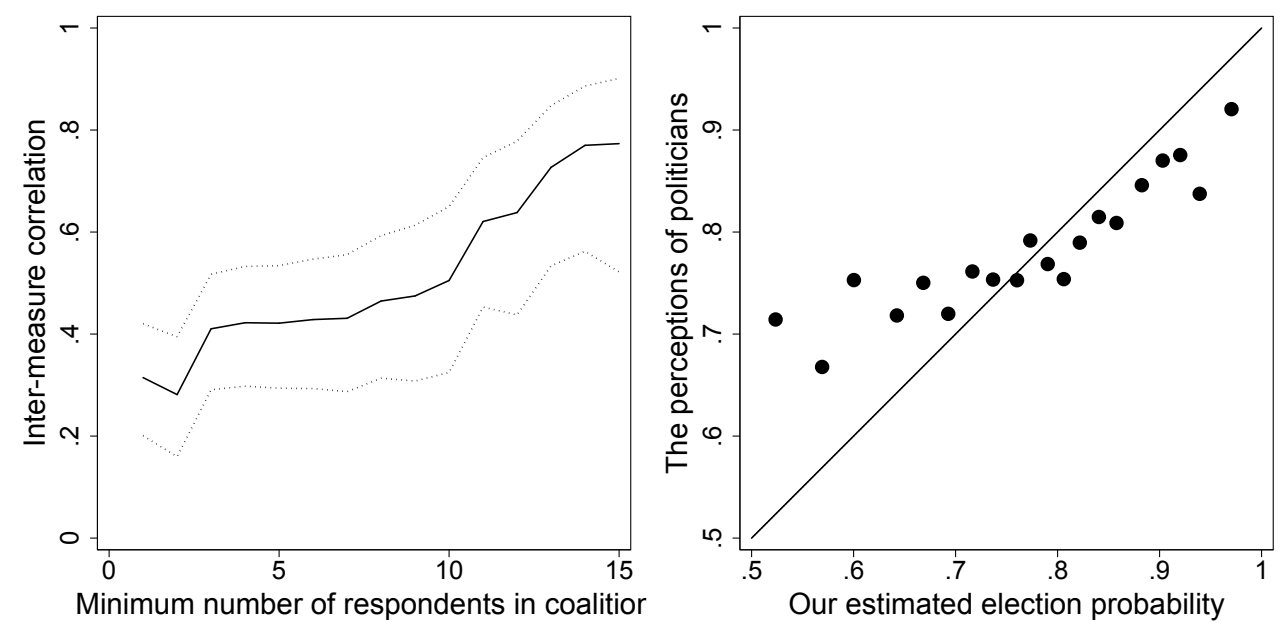

Figure 4: Comparison of the re-election probabilities estimated by our approach for November 2020 with those assessed by the politicians.

in that coalition increases with the number of respondents. Reassuringly, for coalitions with more than 10 respondents, the correlation is much higher than when we also consider coalitions with only a handful of respondents.

Still, with all coalitions considered, the ventile bin scatter-plot in the right panel shows a largely monotonic relationship between the two measures when $p \geq 0.5$. Although the five bins representing the bottom 25 percent of the sample show clear signs of over-confidence, for the remaining observations there is an almost linear relationship between the two measures. Overall, these results suggest that our measure does a fairly good job of capturing the re-election prospects as perceived by the incumbents themselves.

The third validity assessment concerns the predictive capability of the measure. To the extent that one conceives of electoral competitiveness as a function of the probability that the incumbent government will remain in office, it should follow that some predictive power with respect to that probability is a desirable feature of any such measure. Reassuringly for our purposes, Cronert and Nyman (2020, Fig. 4) demonstrate that a measure estimated using their approach is more capable of predicting re-election into office than any previous measure of electoral competitiveness, and that it performs better the shorter the forecasting horizon to the upcoming election, as vote intention polls become more accurate. 


\section{Identification Strategy}

Research on the effects of electoral competitiveness on policy-making predominately relies on empirical strategies where most of the variation in the explanatory variable is found between different governments or electoral terms. However, any factor that makes one government more likely to be re-elected than another government is also likely to influence its policy-making, making such indicators highly susceptible to omitted variable bias that threatens causal inference.

In this paper, we therefore propose a new technique for generating plausibly exogenous variation in electoral competitiveness. To be clear, the problem of omitted variable bias cannot be definitively solved without experimental manipulation. However, we argue that the problem is much smaller if one can instead rely on the temporal variation in re-election probability that is found within a government's term in office. The annual national-level vote intention polls mentioned in the previous section make this possible. By exploiting the fact that changes in the national party preference trends captured in these polls have very different implications for the local governments' re-election probability depending on local factors - such as what parties are part of the government, how these parties performed in the previous election, and what other coalitions could potentially be formed - we achieve a source of variation that is less prone to omitted variable bias. Hence, our identifying variation does not come from the political circumstances that are specific to a certain incumbent government, nor from the changes in the national polls; both these factors are endogenous to policy. Instead, we exploit the variation that results from the interplay between the two factors, while holding all time- and government-specific factors constant using fixed effects for municipality-term and year.

To illustrate this strategy, a useful analogy is the so called Bartik or shift-share instruments (Bartik 1991), that also combine local pre-conditions with national level changes to generate a plausibly exogenous variation at the local level. In the canonical setting, Bartik was interested in estimating the elasticity of wages with respect to job growth. Because job growth is endogenous to the wage level, he instrumented it on the interactions of the local industry shares and the national growth rate in the respective industries, to create a plausibly exogenous source of variation in local job growth. The intuition behind this strategy is that while both the local industry structure and the national job growth are endogenous to wages, plausibly the interaction between the two is not. Although the strategy has received criticism (see Goldsmith-Pinkham, Sorkin, and Swift 2020), it has become a workhorse in 
empirical research on labor, migration and urban development.

Unlike the Bartik instrument, our approach does not rely on an interaction term. Instead, the complex interplay between local pre-conditions and the national polls is modeled in the incumbent re-election probability estimation. As described in the SI (page S1), this procedure takes into account a host of factors, but the party-specific vote intention trends in the annual national polls are the only factors that vary within governments over the election term. As specified in Equation 1, we can therefore simply regress the coming year's policy outcome $\left(y_{i, t+1}\right)$ on our measure of electoral competitiveness $\left(c_{i, t}\right)$ together with fixed effects at the municipality-term $\left(\phi_{i}\right)$ and year $\left(\tau_{t}\right)$ level. The time lag between the outcome and the electoral competitiveness measure is specified because, as noted above, the local tax rate and overarching budget are decided during the fall of the year before they have effect.

$$
y_{i, t+1}=\beta_{1} c_{i, t}+\beta_{2} c_{i, t} \times l_{i}+\boldsymbol{\beta}^{\prime} \boldsymbol{x}_{i, t+1}+\boldsymbol{\phi}_{i}+\boldsymbol{\tau}_{t}+\epsilon_{i, t}
$$

To formally test the two hypotheses, we also include an interaction term between our measure of electoral competitiveness $\left(c_{i, t}\right)$ and a binary indicator for left-wing incumbents ${ }^{11}\left(l_{i}\right)$. Because this indicator is centered around its mean, $\beta_{1}$ tells us whether incumbents on average adjust the policy outcome in response to changes in their re-election probability (for taxation, the myopia hypothesis is that $\left.\beta_{1}<0\right)$. The coefficient for the interaction term $\left(\beta_{2}\right)$ tells us whether incumbents respond to changes in their re-election probability in line with the moderation hypothesis (the hypothesis corresponds to a negative coefficient).

In some specifications we also add a vector of covariates $\left(\boldsymbol{x}_{i, t+1}\right)$. These are the population size (logged), the population density (logged), the share of people aged $0-19$, the share of people older than 64 , the share of households that claim social assistance, the employment rate, the present year's budget balance, and the average value of the dependent variable in the other municipalities in the surrounding region (county). Most of the covariates are included because they are likely to affect the need for public services. The last one - the regional average policy outcome - is meant to control for spatial shocks not captured by the other covariates. For definitions and descriptive statistics, see the SI (page S5).

Throughout our analysis, the sample consists of all years and municipalities between 1998 and 2018 for which the incumbent government has been categorized as either left or right (corresponding to 69 percent of all governments). The reasons for omitting cross-cutting alliances and grand

\footnotetext{
${ }^{11}$ Left-wing incumbents are defined as governments that include one or more of the left-ofcenter parties and no right-of-center party, and vice versa for right-wing incumbents.
} 
coalitions is that it is not evident what the moderation hypothesis implies for governments that are not clearly positioned to the left or the right of the median voter, and that we might not expect any opportunistic behavior at all if there is no clear opposition to the incumbent government.

In our main analyses, we also restrict our sample to municipality-terms where the average incumbent re-election probability $p$ is equal to or greater than 0.5. Within this range, electoral vulnerability $(1-p)$ and electoral competitiveness $(1-|p-0.5|)$ are identical, and we would therefore expect the opportunistic policy response to be a monotonic function of the re-election probability.

\section{Results}

Table 1 reports the results from our main test of the two hypotheses, where the policy outcome $y_{i, t+1}$ is the next year's local income tax rate expressed in percentages (Statistics Sweden 2020a). As described in the previous section, the binary indicator for left-wing incumbency has been centered around its mean. As a consequence, the effect of competitiveness can be interpreted as the opportunistic policy response of an average government. Specifically, if there is myopic behavior, the coefficient for competitiveness will be negative, indicating that the average government reduces taxes. Moderation is instead captured by the interaction between left-wing incumbent and competitiveness. If there is moderating behavior, this coefficient will be negative (left-wing governments are less likely to raise taxes for ideological reasons when competitiveness is high). The table reports three specifications of Equation 1. The first model includes the two variables of interest and fixed effects for the year and municipality-term. The second model adds the aforementioned vector of controls, and the third additionally includes a full set of interactions between those controls, one the one hand, and competitiveness and left-wing incumbency, on the other.

As indicated by the coefficient for the interaction between left-wing incumbents and competitiveness, we find a substantial and statistically significant moderation effect in all three specifications, ranging from -0.54 to -0.90 . To illustrate the size of the effect, a coefficient of -0.5 would imply that the tax rate difference between left-wing and right-wing incumbents decreases by 0.25 percentages points when competitiveness moves from its minimum (0.5) to its maximum (1) value. The evidence for myopic behavior is much more limited. The coefficient for competitiveness is considerably smaller than that of its interaction with left-wing incumbency, and is statistically significant only in Model 1 without time-varying controls. 
Table 1: Average effects of electoral competitiveness on taxation

\begin{tabular}{lccc}
\hline & $(1)$ & $(2)$ & $(3)$ \\
\hline Competitiveness (myopia) & $-0.199^{* *}$ & -0.094 & -0.089 \\
& $(0.077)$ & $(0.073)$ & $(0.071)$ \\
Left-wing $\times$ Competitiveness (moderation) & $-0.541^{* *}$ & $-0.723^{* * *}$ & $-0.901^{* * *}$ \\
& $(0.233)$ & $(0.213)$ & $(0.226)$ \\
\hline Observations & 3,750 & 3,749 & 3,749 \\
Within-period $R^{2}$ & 0.006 & 0.165 & 0.174 \\
Mean of dep. variable & 21.4 & 21.4 & 21.4 \\
Municipality-term and year FE & Yes & Yes & Yes \\
Additional controls & No & Yes & Yes \\
Additional interactions & No & No & Yes \\
\hline
\end{tabular}

Sample restricted to election periods where the average re-election probability is 0.5 or higher and the incumbent government is either left or right. Standard errors in parentheses, clustered by election period (municipality $\times$ election term). ${ }^{*} p<0.10,{ }^{* *} p<0.05,{ }^{* * *} p<0.01$

Two heterogeneity analyses can provide a richer picture of the processes in play here. The first one considers that the norms that guide politics vary across municipalities. This point is evidenced by another question in our politician survey, regarding the extent to which the political culture in the municipality is marked by electoral opportunism. Specifically, we asked "to the extent such a conflict exists, do you perceive that policy-making in your municipality is mainly based on what is best for the municipality in the long term, or on what the governing coalition can do to win the next election?" The item was rated on a five-level Likert item ranging between the two alternatives. For each municipality, we calculate the standardized average score among all respondents, so that higher scores indicate that policy-making is guided more by electoral considerations. The interactions between this measure and our two variables of interest are added to models 1 and 2 of Table 2 (with and without a full set of controls and interactions). The results indicate that politicians' perceptions about the prevalence of electoral opportunism in their municipality's political culture in 2020 are indeed related to the opportunistic behavior observed during the studied period. A one standard deviation increase in this cultural variable entails a 50-60 percent larger-than-average observed moderating effect of electoral competitiveness (cf. Table 1). From a validity perspective, this relationship is a reassuring observation.

Our data furthermore allow us to investigate whether politicians operate 
Table 2: Heterogeneous effects of electoral competitiveness on taxation

\begin{tabular}{lccccc}
\hline & \multicolumn{2}{c}{ Opportunism } & & \multicolumn{2}{c}{ Election year } \\
\cline { 2 - 3 } \cline { 5 - 6 } & $(1)$ & $(2)$ & & $(3)$ & $(4)$ \\
\hline Competitiveness & -0.119 & -0.109 & & -0.079 & -0.051 \\
& $(0.073)$ & $(0.072)$ & & $(0.075)$ & $(0.074)$ \\
Left-wing $\times$ Competitiveness & $-0.626^{* * *}$ & $-0.799^{* * *}$ & $-0.724^{* * *}$ & $-0.926^{* * *}$ \\
& $(0.217)$ & $(0.229)$ & & $(0.212)$ & $(0.222)$ \\
Opportunism $\times$ Competitiveness & -0.006 & -0.000 & & \\
& $(0.093)$ & $(0.095)$ & & \\
Opportunism $\times$ Left-wing $\times$ Comp. & $-0.429^{* *}$ & $-0.461^{* *}$ & & \\
& $(0.193)$ & $(0.198)$ & & \\
Election year $\times$ Competitiveness & & & & $-0.080^{*}$ & $-0.091^{* *}$ \\
& & & & $0.045)$ & $(0.045)$ \\
Election year $\times$ Left-wing $\times$ Comp. & \multicolumn{3}{c}{$0.273^{* * *}$} & $0.246^{* * *}$ \\
& & & & $(0.095)$ & $(0.094)$ \\
\hline Observations & 3,481 & 3,481 & & 3,749 & 3,749 \\
Within-period $R^{2}$ & 0.180 & 0.194 & & 0.168 & 0.184 \\
Mean of dep. variable & 21.3 & 21.3 & & 21.4 & 21.4 \\
Municipality-term and year FE & Yes & Yes & Yes & Yes \\
Additional controls & Yes & Yes & Yes & Yes \\
Additional interactions & No & Yes & No & Yes \\
\hline
\end{tabular}

Sample restricted to election periods where the average re-election probability is 0.5 or higher, and the incumbent government is either left or right. Standard errors in parentheses, clustered by election period (municipality $\times$ election term). ${ }^{*} p<0.10,{ }^{* *} p<0.05,{ }^{* * *} p<0.01$

on the assumption that voters have short memory and primarily respond to events that occur during the election years, or expect them to also remember tax changes taking place earlier in the electoral term (for a discussion, see Healy, Persson, and Snowberg 2017). To this end, models 3 and 4 in Table 2 interact each of our variables of interest with a binary indicator for tax rate decisions pertaining to election years.

Interestingly, rather than revealing any cyclical pattern in the overall opportunistic use of taxation, these models find that myopic behavior intensifies during election years (the interaction between competitiveness and election year is negative and statistically significant), while moderation decreases (the three-way interaction has the opposite sign of the interaction between left-wing incumbent and competitiveness). That myopia is more pronounced during election years is perhaps not surprising, but the results for moderation 
are less intuitive. One possible explanation is that election campaigns are not only about winning voters, but also about mobilizing party activists, and that such mobilization requires that incumbents increasingly cater to the more extreme preferences of these activists at the expense of some moderation.

\section{Robustness Checks}

Notwithstanding these election-year deviations, the analyses above clearly suggest that policy moderation is a more dominant expression of electoral opportunism than policy myopia. A potential objection, however, is that a more straightforward test for policy myopia could use policy outcomes that are less ideologically contested than the tax rate. We have therefore estimated our main models for two additional outcome variables: the budget balance and the proportion of public investments (as share of local GDP), considering that both deficits and under-investment are commonly mentioned as symptoms of policy myopia. These results are presented in the SI, Table S5. The effects of competitiveness on the budget balance are small and not statistically significant. More interestingly, we find a large and statistically significant positive effect of competitiveness on investments, indicating that governments invest more as competitiveness increases. One possible explanation for this result is that fiscal policy in Swedish municipalities is governed by a 'golden rule', which means that local governments are allowed to debt-finance investments, but not tax cuts or current expenditures.

Additional analyses reported in the SI (Tables S6 and S7), show that our results are robust to the use of competitiveness measures based on the reelection probability of the largest incumbent party only; and to the inclusion of cases where the municipality-term-average $p<0.5$, in which case the analysis distinguishes between electoral competitiveness $(1-|p-0.5|)$ and electoral vulnerability $(1-p)$.

\section{Concluding Remarks}

The point of departure for this study was the unfortunate isolation of two important and seemingly unrelated research traditions, concerned with two distinct types of policy responses that may be triggered when political incumbents are uncertain about being re-elected into office: policy myopia and policy moderation. Both these behaviors are opportunistic in the sense that they represent a deviation from the incumbent's preferred policies in an effort to gain an immediate advantage in the electoral competition.

We have here sought to synthesize the two traditions and demonstrate how 
the relative importance of these two behavioral effects of electoral competitiveness can be assessed in a joint analysis, focusing on economic policy-making in Swedish municipalities. In doing so, we have applied Cronert and $\mathrm{Ny}-$ man's (2020) recent measure of electoral competitiveness based on accurate estimates of the incumbents' re-election probability, for which we have generated plausibly exogenous variation by exploiting the interplay between local pre-conditions and national-level vote intention polls.

We observed a substantial moderating effect of competitiveness on incumbents' tax rate decisions - shifting policy towards the median voter-but we found little evidence of policy myopia, whether in taxation, budget balance, or public investments. These contributions have important implications for future research on democratic policy-making.

First, the economic data and the survey data jointly show that politiciansalso at the local level - are both sophisticated and opportunistic, in the sense that they are wary of how their re-election prospects are affected by movements in vote intentions polls and take these prospects into account when making policy. The relevance of vote intention polls documented in this regard contrasts with the larger previous literature that focuses on the policy-making impact of public opinions polls.

Second, it is clear that our findings also contrast with the overall dominance of the myopic perspective among scholars interested in the opportunistic policy effects of elections. This is not to suggest that the stronger emphasis on policy myopia is unwarranted; after all, it is arguably the more problematic of the two behaviors. Over the long term, short-sighted opportunism may harm public finances, lead to public under-investment, and postpone efforts to halt global warming - hence the importance of understanding these mechanisms and creating institutions that mitigate their effects. Furthermore, the lack of myopic behavior observed in the present case might reflect that the institutions in place in Swedish municipalities, such as the balanced-budget rule, have been effective in curbing myopic tendencies. While this does not preclude the possibility of more myopic behavior in other institutional settings, it shows how policy-making can play out in a favorable context.

Opportunistic moderation, on the other hand, does not necessarily constitute a problem. Surely, from the perspective of party activists and core voters, it is disappointing if the party leadership implements policy that is difficult to distinguish from that of the opposition. Over the long term, such behavior may also reinforce sentiments of election futility and deepen the separation of parties and civil society (Katz and Mair 1995; Kirchheimer et al. 1966). On the other hand, to the extent that democracy is about aggregating exogenous preferences into a collective decision, anything that brings policy closer to the median voter would almost by definition be a desirable feature. 
Given this, it is not surprising that myopia has received more scholarly attention than moderation. Nevertheless, our results caution against the popular image among researchers and commentators of politicians as inherently myopic and of the electoral cycle as "an inherent design flaw of democratic systems that produces short political time horizons" (Krznaric 2019).

Painting this more complete and nuanced picture of the opportunistic effects of elections would not have been possible without a measure of electoral competitiveness that lies close to the theoretical concept of interest- the incumbent's re-election probability - and varies over time. While the present study has focused on one specific policy field, set in a favorable informationrich environment, we hope that it will stimulate much-needed scholarly efforts to improve the measurement and causal inferences of electoral competitiveness more broadly, not least in multi-party democracies (Kayser and Lindstädt 2015). Given the centrality of competitive elections in the study of democratic politics, such efforts may be fruitful not only for students of economic policy, but within a large array of fields ranging from voter turnout and accountability, to corruption, climate policy, and public health outcomes.

\section{References}

Abou-Chadi, Tarik and Ellen M Immergut (2019). 'Recalibrating social protection: Electoral competition and the new partisan politics of the welfare state.' European Journal of Political Research 58(2): 697-719.

Abou-Chadi, Tarik and Matthias Orlowski (2016). 'Moderate as necessary: the role of electoral competitiveness and party size in explaining parties' policy shifts.' The Journal of Politics 78(3): 868-881.

Aidt, Toke S, Francisco José Veiga, and Linda Gonçalves Veiga (2011). 'Election results and opportunistic policies: A new test of the rational political business cycle model.' Public Choice 148(1-2): 21-44.

Alesina, Alberto and Guido Tabellini (1990). 'A positive theory of fiscal deficits and government debt.' The Review of Economic Studies 57(3): 403-414.

Alt, James E and Shanna S Rose (2007). 'Context-conditional political budget cycles'. In The Oxford Handbook of Comparative Politics, eds. Carles Boix and Susan C. Stokes. Oxford: Oxford University Press.

Bäck, Hanna (2003). 'Explaining and predicting coalition outcomes: Conclusions from studying data on local coalitions.' European Journal of Political Research 42(4): 441-472. 
Bartik, Timothy J (1991). Who Benefits From State and Local Economic Development Policies? Kalamazoo, MI: WE Upjohn Institute for Employment Research.

Bernardi, Luca (2018). 'Policy Responsiveness and Electoral Incentives: A (Re)assessment.' Political Behavior: 1-24.

Bowen, William G, Richard G Davis, and David H Kopf (1960). 'The public debt: A burden on future generations?' The American Economic Review 50(4): 701-706.

Boyne, George A (1998). 'Party competition and local spending decisions.' British Journal of Political Science 28(1): 185-222.

Canes-Wrone, Brandice and Kenneth W Shotts (2004). 'The conditional nature of presidential responsiveness to public opinion.' American Journal of Political Science 48(4): 690-706.

Clingermayer, James C and B Dan Wood (1995). 'Disentangling patterns of state debt financing.' American Political Science Review 89(1): 108-120.

Cronert, Axel and Pär Nyman (2020). 'A General Approach to Measuring Electoral Competitiveness for Parties and Governments.' Political Analysis First View, https://doi.org/10.1017/pan.2020.30.

Dahl, Robert (1971). Polyarchy. New Haven: Yale University Press.

Dancygier, Rafaela M, Karl-Oskar Lindgren, Pär Nyman, and Kåre Vernby (2020). 'Candidate Supply Is Not a Barrier to Immigrant Representation: A Case-Control Study.' American Journal of Political Science Early View, https://doi.org/10.1111/ajps.12553.

Downs, Anthony (1957). An Economic Theory of Democracy. New York: Harper.

Efthyvoulou, Georgios (2012). 'Political budget cycles in the European Union and the impact of political pressures.' Public Choice 153(3-4): 295-327.

Elkins, David J (1974). 'The measurement of party competition.' American Political Science Review 68(2): 682-700.

Eslava, Marcela (2011). 'The political economy of fiscal deficits: a survey.' Journal of Economic Surveys 25(4): 645-673.

Ferreira, Fernando and Joseph Gyourko (2009). 'Do political parties matter? Evidence from US cities.' The Quarterly Journal of Economics 124(1): 399-422.

Folke, Olle (2014). 'Shades of brown and green: party effects in proportional election systems.' Journal of the European Economic Association 12(5): 1361-1395.

Frey, Bruno S (1978). 'Politico-economic models and cycles.' Journal of Public Economics 9(2): 203-220. 
Frey, Bruno S and Friedrich Schneider (1978). 'An Empirical Study of PoliticoEconomic Interaction in the United States.' The Review of Economics and Statistics 60(2): 174-183.

Goldsmith-Pinkham, Paul, Isaac Sorkin, and Henry Swift (2020). 'Bartik instruments: What, when, why, and how.' American Economic Review 110(8): 2586-2624.

Healy, Andrew J, Mikael Persson, and Erik Snowberg (2017). 'Digging into the pocketbook: Evidence on economic voting from income registry data matched to a voter survey.' American Political Science Review 111(4): 771-785.

Hobolt, Sara Binzer and Robert Klemmensen (2008). 'Government responsiveness and political competition in comparative perspective.' Comparative Political Studies 41(3): 309-337.

Hübscher, Evelyne and Thomas Sattler (2017). 'Fiscal consolidation under electoral risk.' European Journal of Political Research 56(1): 151-168.

Immergut, Ellen M and Tarik Abou-Chadi (2014). 'How electoral vulnerability affects pension politics: Introducing a concept, measure and empirical application.' European Journal of Political Research 53(2): 269-287.

Jacobs, Alan M (2011). Governing for the Long Term: Democracy and the Politics of Investment. Cambridge University Press.

Katz, Richard S and Peter Mair (1995). 'Changing models of party organization and party democracy: the emergence of the cartel party.' Party Politics 1(1): 5-28.

Kayser, Mark Andreas and René Lindstädt (2015). 'A cross-national measure of electoral competitiveness.' Political Analysis 23(2): 242-253.

Kirchheimer, Otto et al. (1966). 'The transformation of the Western European party systems.' Political parties and political development 6: 177-200.

Kramer, Gerald H (1971). 'Short-term fluctuations in US voting behavior, 1896-1964.' American Political Science Review 65(1): 131-143.

Krznaric, Roman (2019). Why we need to reinvent democracy for the long-term. 19th March 2019. https://www.bbc.com/future/article/20190318-can-wereinvent-democracy-for-the-long-term.

Kuhlmann, Sabine and Hellmut Wollmann (2014). Public Administration and Administrative Reforms in Europe. An Introduction in Comparative Public Administration. Cheltenham: Edward Elgar.

Lee, David S, Enrico Moretti, and Matthew J Butler (2004). 'Do voters affect or elect policies? Evidence from the US House.' The Quarterly Journal of Economics 119(3): 807-859.

Nordhaus, William D (1975). 'The political business cycle.' The Review of Economic Studies 42(2): 169-190. 
Oscarsson, Henrik and Sören Holmberg (2016). 'Issue Voting Structured by Left-Right Ideology'. In The Oxford Handbook of Swedish Politics, eds. Jon Pierre. Oxford: Oxford University Press.

Persson, Torsten and Lars EO Svensson (1989). 'Why a stubborn conservative would run a deficit: Policy with time-inconsistent preferences.' The Quarterly Journal of Economics 104(2): 325-345.

Pettersson-Lidbom, Per (2001). 'An empirical investigation of the strategic use of debt.' Journal of Political Economy 109(3): 570-583.

Pettersson-Lidbom, Per (2008). 'Do parties matter for economic outcomes? A regression-discontinuity approach.' Journal of the European Economic Association 6(5): 1037-1056.

Pickup, Mark and Sara B Hobolt (2015). 'The conditionality of the tradeoff between government responsiveness and effectiveness: The impact of minority status and polls in the Canadian House of Commons.' Electoral Studies 40: 517-530.

Price, Simon (1998). 'Comment on 'The politics of the political business cycle'.' British Journal of Political Science 28(1): 185-222.

Robertson, David Bruce (1976). A Theory of Party Competition. John Wiley $\&$ Sons.

Rogoff, Kenneth and Anne Sibert (1988). 'Elections and macroeconomic policy cycles.' The Review of Economic Studies 55(1): 1-16.

Rogoff, Kenneth S (1990). 'Equilibrium political budget cycles.' The American Economic Review 80(1): 21-36.

Sartori, Giovanni (1976). Parties and Party Systems: A Framework for Analysis. Cambridge: Cambridge University Press.

Schultz, Kenneth A (1995). 'The politics of the political business cycle.' British Journal of Political Science 25(1): 79-99.

Schumacher, Gijs and Patrik Öhberg (2020). 'How do politicians respond to opinion polls? An experiment with Swedish politicians.' Research \&6 Politics 7(3): 1-6.

Schumpeter, Joseph A (1950). Socialism, Capitalism and Democracy. Harper and Brothers.

Seiferling, Mike (2020). 'Fiscal deficits and executive planning horizons.' Political Science Research and Methods 8(2): 329-343.

SKR (2018). Maktfördelning i kommuner, landsting och regioner 1994-2014.

Database. Swedish Association of Local Authorities and Regions (SKL).

Soroka, Stuart N and Christopher Wlezien (2010). Degrees of Democracy:

Politics, Public Opinion, and Policy. Cambridge University Press.

Statistics Sweden (2018). General elections, results. Online Database.

Statistics Sweden (2020a). Local taxes. Online Database.

Statistics Sweden (2020b). Party Preference Survey (PSU). Online Database. 
Strøm, Kaare (1989). 'Inter-party competition in advanced democracies.' Journal of Theoretical Politics 1(3): 277-300.

Strøm, Kaare (1990). 'A behavioral theory of competitive political parties.' American Journal of Political Science 34(2): 565-598.

Strotz, Robert Henry (1955). 'Myopia and inconsistency in dynamic utility maximization.' The Review of Economic Studies 23(3): 165-180.

Svaleryd, Helena and Jonas Vlachos (2009). 'Political rents in a non-corrupt democracy.' Journal of Public Economics 93(3-4): 355-372.

Weibull, Lennart, Sören Holmberg, Henrik Oscarsson, Johan Martinsson, and Elias Markstedt (2014). Super-Riks-SOM 1986-2013, v2014.1. Dataset.

Wittman, Donald (1983). 'Candidate motivation: A synthesis of alternative theories.' American Political Science Review 77(1): 142-157. 